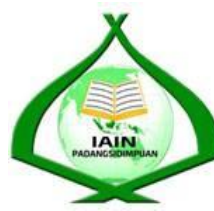

ENGLISH EDUCATION

English Journal for Teaching and Learning

Vol. 07 No. 01 June 2019 page 59 - 68

http://jurnal.iain-padangsidimpuan.ac.id/index.php/EEJ

Noun in "Silly Questions"

\title{
Zainuddin Zainuddin*
}

Institut Agama Islam Negeri (IAIN) Padangsidimpuan

Email : zainuddin.iainpsp@gmail.com

Abstract The researcher focuses the study on Noun for "Silly Questions" in English is Fun (book). The research is done through descriptive qualitative, in which the aims of the research are to describe Noun for "Silly Questions" in English is Fun (book), which is based on kinds of Concrete Noun; Proper Noun, Common Noun, Material Noun, and Collective Noun. Additionally, here the researcher tries to determine the dominant use of kinds of Concrete Noun. Consequently, the researcher takes "Silly Questions" for primary data, and then some related Journals and books about Noun. Furthermore, the researcher uses content analysis method for analyzing the data. There the technique of analyzing the data; Reading 15 Silly Questions and its answers, signing kinds of Concrete Noun in the 15 Silly Questions, and then giving found kinds of Concrete Noun explanations. Finally, having conclusion of overall discussion. In conclusion, there are 43 Concrete Nouns; They are eight Proper Nouns, 26 Common Nouns, one Material Noun, and eight Collective Nouns for 15 Silly Questions in English is Fun (book) as the result of the research.

Keywords: Silly; Concrete Noun; Dominant; Common Noun; Collective Noun.

Abstrak Peneliti memfokuskan penelitiannya pada kelas kata Nomina yang terdapat dalam "Silly Questions" pada buku English is Fun. Penelitian ini dilaksanakan dengan menggunakan metode descriptive qualitative, dan bertujuan untuk menemukan kelas kata Nomina yang berjenis kongkrit seperti Proper Noun, Common Noun, Material Noun, dan Collective Noun. Kemudian memberi gambaran atau penjelasan atas temuan tersebut. Selanjutnya, Peneliti menentukan penggunaan kelas kata Nomina yang berjenis kongkrit dan lebih dominan dan yang paling sedikit penggunaannya pada "Silly Questions" pada buku English is Fun. Penelitian ini menggunakan "Silly Questions" pada buku English is Fun sebagai data primer, dan data dianalisa dengan menggunakan metode content analysis. Data penelitian dianalisa dengan cara; Membaca 15

\footnotetext{
*Corresponding Author : zainuddin.iainpsp@gmail.com
} 
soal yang terdapat pada "Silly Questions" pada buku English is Fun. Menemukan dan menandai kelas kata Nomina yang berjenis kongkrit, kemudian memberi gambaran atau penjelasan pada hasil temuan tersebut. Akhirnya, Peneliti menyimpulkan proses dan hasil temuan pada penelitian ini. Sebagai penutup, hasil temuan dari penelitian ini adalah Peneliti menemukan 43 kelas kata Nomina yang berjenis kongkrit yang terdapat pada "Silly Questions" pada buku English is Fun, yaitu: Delapan kelas kata Proper Noun, 26 kelas kata Common Noun, Satu kelas kata Material Noun, dan delapan kelas kata Collective Noun.

Kata Kunci: Silly; Concrete Noun; Dominant; Common Noun; Collective Noun

\section{INTRODUCTION}

Stupid, Foolish, and Silly really do all mean the same thing. But they come from different word. Stupid comes from Latin 'stupor', Foolish comes from French 'fou', and Silly comes from Old English word "saelig'. ${ }^{1}$ Moreover, Stupid (Adj) 'slow-thinking'; kurangnya pengetahuan. E.g. Budi, don't lock the door! I can't go out! You are stupid!. Foolish (Adj) 'without reason, sense good judgment'; kebodohan yang disengaja. E.g. Wati felt very foolish standing there with only one sandal on. Silly (Adj) 'weak-minded'; konyol. E.g. Ani loves Andi because Andi is a silly man. ${ }^{2}$

Specifically, Silly question means a question with low intellectuality unlike questions which have a good understanding in them. Generally, silly question lack common sense in them and they are mostly asked by children or people who have childish brain or people have higher capability of brain.

Beside, Grammar is study or science of rules for the combination of words into sentences, and the forms of words. ${ }^{3}$ In other words, it is a study about sub system of language organization in which meaningful units of language are gathered for larger unit formulations. Precisely, it is divided into Morphology

\footnotetext{
${ }^{1}$ Typepad.com.Friday,19th2019.21.25 Wib.

2 Hornby, A.S, A P Cowie, et. al., Oxford Advanced Learner's Dictionary of Current English(New York: Oxford University Press, 1974). Page 375.

3 A.V. Martinet, A.J. Thomson, A Practical English Grammar (London: Oxford University Press, 1986) Page 65.
} 
and Syntaxes, and more over it does not belong to Phonology, Semantics and lexicon. 4

Grammar is a part of compulsory study in English mastery. Whole English learners should study and master grammar as best as learners can. English learners might get grammar study from guided (school) or none guided (selfstudy through grammar books). Learners use grammar mastery for owngoodness in English practice orally or written expression.

English practice without well grammar mastery is a joke and seems like a useless English practice. Additionally, the goals of English practice orally or written expression is not reachable, and it might give misunderstanding and misinterpretation in English practice. However, the researcher realizes that grammar use is mostly practiced in written expression of English practice rather than oral expression of English practice.

There are many lessons in grammar study. Thus, English learners strongly suggested starting studying English through grammar since learners in kindergarten level of study up to university level. Learners might best start from mustering Parts of Speech and then 16 Tenses of English and so on.

Thus, the researcher here, would like to discuss about Noun; Kinds of Concrete Noun for "Silly questions" in English is Fun (book). Consequently, Reading the Silly Questions and its answers, signing kinds of Concrete Noun in the Silly Questions, and then giving found kinds of Concrete Noun. Explanations. Finally, having conclusion of overall discussion are parts of research data analyzing techniques.

Improving Students' Speaking Participation in Asking Question by Using Planted Question Technique. By A. Ramadhan. This research discussed the use of planted question technique to improve students' speaking participation in asking question. This research was conducted to the eight grade b students of MTs Negeri 1 Mempawah Hilir. There were thirty six students.

Teacher Questioning in Classroom Interaction. By: Sarlita Dewi Matra. Questions play an important role in every classroom both students' questions and teachers' questions. The type of questions used by teacher can help students

${ }^{4}$ Kridalaksana, Harimurti. Kamus Linguistik (Jakarta:PT Gramedia Pustaka Utama, 2001). Page 66. 
to lift their own levels of understanding toward the concept given or even to build up new ideas.

Teaching oral language : building a firm foundation using ICPALER in the early primary years. Oral language skills are an essential foundation for successful school learning. However, until recently, the acquisition of oral language skills has been largely over shadowed by reading, writing, spelling, and numeracy. In teaching oral language, Dr John Munro redresses this imbalance through the delivery of his step-by-step model: ICPALER (IdeasConventions-Purposes-Ability to Learn-Expression and Reception).

\section{METHOD}

The research is done through descriptive qualitative, in which the aims of the research are to describe Noun for "Silly Questions" in English is Fun (book), which is based on kinds of Concrete Noun; Proper Noun, Common Noun, Material Noun, and Collective Noun.

Moreover, here the researcher tries to determine the dominant use of kinds of Concrete Noun. Consequently, the researcher takes "Silly Questions" for primary data, and then some related Journals and books about Noun. Furthermore, the researcher uses content analysis method for analyzing the data.

There the technique of analyzing the data; Reading 15 Silly Questions and its answers, signing kinds of Concrete Noun in the 15 Silly Questions, and then giving found kinds of Concrete Noun explanations. Finally, having conclusion of overall discussion.

\section{RESULT AND DISCUSSION}

Stupid (Adj) 'slow-thinking'; kurangnya pengetahuan. E.g. Budi, don't lock the door! I can't go out! You are stupid! Foolish (Adj) 'without reason, sense good judgment'; kebodohan yang disengaja. E.g. Wati felt very foolish standing there with only one sandal on. Silly (Adj) 'weak-minded'; konyol. E.g. Ani loves Andi because Andi is a silly man.

Whereas, Silly question means a question with low intellectuality unlike questions which have a good understanding in them. Generally, silly question 
lack common sense in them and they are mostly asked by children or people who have childish brain or people have higher capability of brain.

There it is "Silly question" in English is Fun (book):

1. Your aunt has a brother and this is not your uncle, who is he?

2. What is full of holes and holds water?

3. What is the longest word in the English language?

4. Can a kangaroo jump higher than the empire state building?

5. Where does Monday come before Sunday?

6. Write down the following amount; twelve thousand, twelve hundred and twelve.

7. What is the capital in England?

8. Mr. Smith has five sons, each son has a sister. How many children does Mr. Smith have?

9. Do you stir your tea with your right or your left hand?

10.It has four legs but can't walk or run. What is it?

11.Which weighs more, a ton of steel or a ton of water?

12.Twice in a moment, once in a minute, never in an hour, what is it?

13.What word is always spelled wrong?

14. You go to bed at seven in the evening and set your alarm to wake you up the next morning at eight o'clock. How many hours will you sleep before being awakened by the alarm?

15.What is in the middle of Paris?

Grammar is study or science of rules for the combination of words into sentences, and the forms of words. In other words, it is a study about sub system of language organization in which meaningful units of language are gathered for larger unit formulations. Precisely, it is divided into Morphology and Syntaxes, and more over it does not belong to Phonology, Semantics and lexicon.

Moreover, there are many lessons in grammar study, such as Parts of Speech and then 16 Tenses of English and so on. In this research, the researcher only tries to find and describe Noun; Kinds of Concrete noun; Proper Noun; Noun indicates people's names, countries, and even some common written words in capital letters. Common Noun; Common written words in small letters. 
, Material Noun; Noun indicates building materials or mining. And Collective Noun; Noun indicates a group of things for "Silly question" in English is Fun (book):

There they are Kinds of Concrete noun for "Silly questions" in English is Fun (book):

Table I

Concrete nouns for "Silly questions" in English is Fun (book):

\begin{tabular}{lll}
\hline No & \multicolumn{2}{c}{ Concrete Nouns } \\
\cline { 3 - 4 } 1. & Proper Noun & Common Noun Material Noun Collective Noun \\
& & aunt, brother, \\
& uncle \\
2. & holes, water \\
3. English & word \\
& language & \\
4. & & kangaroo, \\
& & empire, state, \\
& building
\end{tabular}

5. Monday, Sunday

6.

Twelve

amount

thousand,

twelve hundred,

twelve.

7. England capital

8. Mr. Smith sons, sister,

children

9.

hand

tea

10.

legs

11.

weighs, a ton of steel, ton of water

12.

Twice in a 


\section{moment, once in \\ a minute, never in \\ an hour}

$13 . \quad$ word

14. Evening, bed, seven, hours

Morning, alarm, you,

eight, o'clock,

15. Paris

(table 3 continue)

Table II

Result of Concrete nouns for "Silly questions" in English is Fun (book)

\begin{tabular}{ccc}
\hline No & Concrete Nouns & Result \\
\hline $\mathbf{1}$ & Proper Noun & 8 \\
$\mathbf{2}$ & Common Noun & 26 \\
$\mathbf{3}$ & Material Noun & 1 \\
$\mathbf{4}$ & Collective Noun & 8 \\
& Total & $\mathbf{4 3}$ \\
\hline
\end{tabular}

Note:

1. There are 15 Silly Questions in English is Fun (book). By: David L. Larcom

2. Noun; Kinds of Concrete noun; Proper Noun; Noun indicates people's names, countries, and even some common written words in capital letters. Common Noun; Common written words in small letters.

Material Noun; Noun indicates building materials or mining. And Collective Noun; Noun indicates a group of things.

3. Looking at the above table, the researcher may state that there are 43 Concrete Nouns for "Silly Questions" in English is Fun (book).

4. There are eight Proper Nouns for "Silly Questions" in English is Fun (book). 
5. There are 26 Common Nouns for "Silly Questions" in English is Fun (book).

6. There is one Material Noun for "Silly Questions" in English is Fun (book).

7. There are eight Collective Nouns for "Silly Questions" in English is Fun (book).

8. There they are above table explanations. There are only three Common Nouns; aunt, brother, uncle in number one question. There are two Common Nouns; holes, water in number two question. There are one Proper Noun; English language and one Common Noun; word in number three question. There are four Common Nouns; kangaroo, empire, state, building in number four question. There are two Proper Nouns; Monday, Sunday in number five question. There are three Common Nouns; twelve thousand, twelve hundred, twelve. And one Collective Noun; amount in number six question. There are one Proper Noun; England and one Common Noun; capital in number seven question. There are one Proper Noun; Mr. Smith and three Common Nouns; sons, sister, children in number eight question. There are one Common Noun; hand and one Material Noun; tea in number nine question. There is one Common Noun; legs in number ten question. There are three Collective Nouns; weighs, a ton of steel, ton of water in number eleven. There are three Collective Nouns; twice in a moment, once in a minute, never in an hour in number twelve question. There is one Common Noun; word in number thirteen. There are two Proper Nouns; Evening, Morning, six Common Nouns; bed, seven, alarm, you, eight, o'clock, and one Collective Noun; hours in number fourteen question. There is one Proper Noun; Paris in number fifteen question.

From the result of this research, it can be seen that Silly Questions of Noun in English is Fun (book) had found 43 concrete nouns, 8 proper nouns, 26 common nouns, and 8 collective nouns. Comparing with a research by $\mathrm{A}$. Ramadhan, he discussed about students' speaking participation in asking question by using planted question technique. He had found that the planted 
question technique can improve students' speaking participation in asking question. The differences of both researches were in the topic and purpose. Line with topic the researcher used Silly Question in Noun while Ramadhan used planted question, moreover in purposes the researcher used text book to analyze while Ramadhan used technique to improve students' speaking participation.

\section{CONCLUSION}

Here, the researcher would like to conclude that:

1. Grammar is study or science of rules for the combination of words into sentences, and the forms of words.

2. Noun; Kinds of Concrete noun; Proper Noun; Noun indicates people's names, countries, and even some common written words in capital letters. Common Noun; Common written words in small letters. , Material Noun; Noun indicates building materials or mining. And Collective Noun; Noun indicates a group of things

3. There are 15 Silly Questions in English is Fun (book). By: David L. Larcom

4. There are 43 Concrete Nouns for "Silly Questions" in English is Fun (book).

5. There are eight Proper Nouns, 26 Common Nouns one Material Noun, and eight Collective Nouns for "Silly Questions" in English is Fun (book).

6. The most dominant use of kinds of Concrete Nouns for "Silly Questions" in English is Fun (book) is Common Noun, and the least use one is Material Noun.

7. The title of book in which the researcher takes Silly Questions as the primary data of the research is "English Is Fun". It was written by David L. Larcom. It is published by Kesaint Blanc, in JakartaIndonesia, 2008.

8. There are 43 Concrete Nouns for "Silly Questions" in English is Fun (book): - Proper Nouns; English language, Monday, Sunday, England, Mr. Smith, Evening, Morning, and Paris. Common Nouns; aunt, brother, 
uncle, holes, water, word, kangaroo, empire, state, building, twelve thousand, twelve hundred, twelve, capital, sons, sister, children, hand, legs, bed, seven, alarm, you, eight, o'clock, and word. Material Noun; tea. Collective Nouns; amount, weighs, a ton of steel, ton of water, twice in a moment, once in a minute, never in an hour, and hours.

\section{REFERENCES}

Azar, B.S., Understanding and Using English Grammar (Jakarta: Binarupa Aksara, 1993. Page 24. Chapter 1.

Ary, Donald et.al, Introduction to Research in Education, USA: Wadsworth, 2010

Amirul Hadi \& Haryono, Metodologi Penelitian, Bandung: Pustaka Setia, 1998.

Gay L.R. and Peter Airasian, Education Research: Competence for Analysis and Application, USA: Prectice Hall, 2000.

Halliday, M.A.K. Intorudction to Functional Grammar, New York: Routledge, 2014.

Harmer, Jeremy, The Practice of English Language Teaching, (London: Longman, 2001.

Hornby, A.S, A P Cowie, et. al., Oxford Advanced Learner's Dictionary of Current English. New York: Oxford University Press, 1974.

Kridalaksana, Harimurti. Kamus Linguistik. Jakarta-Indonesia: PT Gramedia Pustaka Utama, 2001. Page 66.

Krohn, Robert. English Sentence Structure. America: The University of Michigan, 1971.

Larcom. L.D. English Is Fun (Jakarta-Indonesia: Kesaint Blanc, 2008). Mason, Jenifer Qualitative Research, London: SAGE Publications, 2002.

Maclin,A. Reference guide to English: a handbook of English as a second language. Washington, D.C.: the Materials Branch, English Language Programs Division, United States Information Agency, 1996.

Noeng Muhadja, Metodologi Peneltian Kualitatif, Yogyakarta: Rake Sarasan, 1992 Quora/https://www.quora.com.Monday,15-04-2019. 20.45 Wib.

Suharsimi Arikunto, Prosedur Penelitian Suatu Pendekatan Praktik, Jakarta: Rineka Cipta, 2006

Thomson, A.J. A Practical English Grammar (New York: Oxford University Press, 1986). 